\title{
Pengaruh Ekstrak Daun Turi Merah Terhadap Kadar Tgf- $\beta$ Pada Mencit Model Infeksi Nifas
}

\author{
Raden Maria VeronikaWidiatrilupi ${ }^{1}$ \\ ${ }^{1}$ Program Studi D III Kebidanan \\ Politeknik kesehatan RS dr.Soepraoen Malang \\ E-mail :maria_pratista@yahoo.com
}

\begin{abstract}
ABSTRAK
Infeksi puerperalis merupakan masalah yang banyak terjadi pada ibu post partum di negara-negara berkembang. Bakteri yang umum ditemukan pada infeksi nifas salah satunya adalah bakteri gram positif Streptococcus agalactiae. 5-30\%. Infeksi postpartum yang disebabkan oleh bakteri ini adalah endometritis.Bakteri Streptococcus agalactiae merupakan bakteri gram positif yang berbentuk coccus dimana menghasilkan toksin berupa eksotoksin sitotoksik dan komponen dinding sel bakteri.Tubuh mempunyai suatu mekanisme untuk mengimbangi respon imun proinflamatori yang berlebih yang dimediasi Th1, yaitu dengan respon Th2 yang menginduksi produksi Transforming Growth Factor (TGF- $\beta$ ). Tujuan makalah ini untuk membuktikan ekstrak daun turi merah dapat mempengaruhi kadar TGF- $\beta$ pada mencit model infeksi nifas yang diinokulasi bakteri Sterptococcus agalactiae.
\end{abstract}

Kata Kunci : Ekstrak turi merah, Streptococcus agalactiae, dan TGF- $\beta$

\begin{abstract}
Puerperalis infection is a common problem for post-partum mothers in developing countries. Bacteria commonly found in postpartum infections one of them is the gram-positive bacterium Streptococcus agalactiae. 5-30\%. Postpartum infection caused by this bacteria is endometritis. Streptococcus agalactiae is a gram-positive bacterium in the form of coccus which produces toxin in the form of cytotoxic exotoxins and bacterial cell wall components. The body has a mechanism to offset the Th1-mediated excess proinflammatory immune response, which is the Th2 response that induces the production of Transforming Growth Factor (TGF- $\beta$ ). The purpose of this paper to prove red turi leaf extract can affect the levels of TGF- $\beta$ in the mice of infertile infection inoculated by Sterptococcus agalactiae bacteria.
\end{abstract}

Keywords: Red turi extract, Streptococcus agalactiae, and TGF- $\beta$ 


\section{PENDAHULUAN}

Masalah kesehatan reproduksi wanita menjadi perhatian yang perlu dipertimbangkan, terutama pada ibu setelah persalinan. Saat proses persalinan sering kali terjadi robekan jalan lahir, baik robekan spontan atau dengan pembedahan yang mempermudah terjadinya infeksi. Di negara berkembang, angka kematian ibu di periode post partum menduduki rata-rata lebih tinggi, yaitu (40\%) dibandingkan periode antenatal maupun intranatal [1].Penyebab kematian ibu yang paling besar adalah perdarahan $28 \%$ dan infeksi sebanyak $11 \%$ [2]. Adanya kesenjangan antara cakupan persalinan tahun 2013 yang ditolong oleh tenega kesehatan mencapai 90,88\%, namun cakupan kunjungan masa nifas hanya $86,64 \%$ belum setinggi cakupan persalinan yang ditolong oleh tenega kesehatan. Dengan adanya kesenjangan antara cakupan persalinan dan cakupan kunjungan nifas oleh tenaga kesehatan ini dapat menyebabkan komplikasi pada masa nifas tidak terkontrol secara efekif, termasuk infeksi yang terjadi pada masa nifas [3].

Kehadiran bakteri melalui jalan lahir yaitu vagina dan jalan lain saat persalinan maupun setelah persalinan dapat menjadi faktor resiko terjadinya infeksi nifas ${ }^{4}$. Organisme yang menyerang bekas implantasi plasenta atau laserasi akibat persalinan dapat berasal dari bakteri penghuni normal serviks dan jalan lahir, atau dari luar. Strain bakteri yang paling umum diisolasi pada infeksi masa nifas salah satunya yaitu bakteri gram positif Streptococcus agalactiae [4,5].

Bakteri Streptococcus agalactiae termasuk kedalam genus grup B Streptococcus.Bakteri ini merupakan bakteri gram positif yang secara normal ditemukan pada vagina, usus, dan orofaring manusia.Streptococcus agalactiae merupakan penyebab utama terjadinya kelahiran prematur, ketuban pecah dini, infeksi postpartum, pneumonia, meningitis, dan sepsis pada neonatus.Kira-kira 5-30\%. Infeksi postpartum yang disebabkan oleh bakteri ini adalah endometritis $[5,6,7]$.

Bakteri Streptococcus agalactiae (SGB) merupakan bakteri gram positif yang berbentuk coccus, bersifat patogen, menghasilkan toksin berupa eksotoksin sitotoksik dan komponen dinding sel bakteri yang terdiri dari Peptidoglycan (PepG) dan lipoteichoic acid (LTA).

LTA yang merupakan salah satu substansi Pathogen Associated Molecular Patterns (PAMPs). Substansi PAMPs merupakan bagian dari patogen yang akan dikenali Toll-like Receptor (TLR), selanjutnya bila diikat oleh TLR akan memicu aktifasi dari neutrofil serta makrofag. Makrofag yang teraktivasi akan mensekresi sitokin proinflamasi seperti TNF- $\alpha$, IL-1, IL-6 dan IL-8. Peningkatan konsentrasi TNF- $\alpha$ yang di produksi oleh Th1 secara berlebihan dalam darah mempunyai hubungan dengan syok sepsis dan kematian pada kasus SGB, bahkan dikatakan bahwa TNF- $\alpha$ adalah mediator kematian pada kasus infeksi SGB $[8,9,10,11,12,13$, $14]$.

Respon proinflamatori yang berlebihan akan mengakibatkan kerusakan jaringan yang tidak terkontrol dan terjadinya syok septik. Tubuh mempunyai suatu mekanisme untuk mengimbangi respon imun proinflamatori yang berlebih yang dimediasi Th1 ini, yaitu dengan respon Th2 yang menginduksi produksi TGF- $\beta$ [15]. Pengobatan terhadap infeksi Streptococcus agalactiae salah satunya dengan pemberian antibiotik. Salah satu herbal alam yang memiliki efek antibakteri dan imunomodulator adalah Sesbania Grandiflora L. Pers (turi merah) yang banyak tumbuh di daerah tropis Indonesia.

Daun turi merah yang memiliki kandungan saponin, flavonoid dan tanin yang mempunyai fungsi sebagai antibakteri. Kandungan Etanol yang terdapat pada ekstrak daun turi merah mempunyai fungsi sebagai imunomodulator $[16,17]$. Secara in vitro zat aktif dalam daun 
turi merah mempunyai efek menghambat pertumbuhan bakteri (bakteriostatik) pada kadar hambat minimal (KHM) $14 \%^{18 .}$

\section{TINJAUAN PUSTAKA \\ Nifas}

Masa nifas adalah suatu periode beberapa minggu setelah kelahiran. Lamanya periode ini tak pasti, sebagian besar menganggapnya antara 4 sampai 6 minggu [18].

beberapa masalah kesehatan yang muncul pada saat masa nifas diantaranya perdarahan pascapartum, infeksi nifas (puerperium), preeclampsia/eklampsia, tromboemboli, infeksi mammae dan komplikasi perkemihan.Infeksi puerperium biasanya disebabkan oleh adanya bakteri yang masuk melalui alat genetalia pada saat persalinan maupun setelahnya dengan gejala suhu meningkat, lochea berbau dan nyeri pada tempat infeksi [19].

\section{Infeksi Nifas}

Infeksi nifas adalah istilah untuk menjelaskan setiap infeksi bakteri di saluran genital setelah persalinan [18]. Sekitar 6077 pasien di Rumah Sakit Khanevadeh dari tahun 2003 sampai dengan 2008 sebanyak 461 pasien diantaranya mengalami infeksi postpartum. Adapun jenis bakteri yang berhasil diisolasi terdiri dari bakteri aerob, anaerob cocci serta basilli.Bakteri aerob yang ditemukan salah satunya adalah Streptococcus agalactiae [20].

\section{Patogenesis Infeksi Nifas}

infeksi nifas setelah persalinan pervaginam biasanya terjadi terutama mengenai daerah bekas implantasi plasenta. Sedangkan infeksi nifas setelah persalinan seksio sesarea adalah infeksi luka operasi.Sewaktu persalinan bakteri yang berada di serviks dan vagina mendapat akses masuk melalui cairan amnion.Kecenderungan terjadinya Infeksi nifas bergantung pada mekanisme pertahanan rahim host.Perubahan yang terjadi pada konsentrasi hormon steroid termasuk estrogen, progresteron, glukokortikoid dan metabolisme arachidonic acid saat mendekati persalinan berperan penting dalam menekan fungsi leukosit, sehingga menyebabkan pada masa nifas rentan terhadap terjadinya infeksi [21].

Selain itu, pada awal postpartum, jumlah dan fungsi limfosit seperti proliferasi sel, pembentukan antibodi dan produksi sitokin menurun. Penurunan dari pertahanan imun host ini berkontribusi pada patogenesis terjadinya infeksi. Terjadinya penurunan dari produksi sitokin pada masa postpartum menyebabkan perubahan pada respon imun tertentu dan meningkatkan kerentanan host terhadap infeksi [22].

\section{Streptococcus agalactiae}

Streptococcus merupakan bakteri gram positif berbentuk cocci yang biasanya tersusun dalam rantai panjang dan berpasanganan.Banyak spesies merupakan anggota dari mikroflora normal pada membran mukosa dari manusia ataupun hewan, dan beberapa bersifat patogen. Streptococcus sp. digolongkan berdasarkan kombinasi sifatnya, antara lain sifat pertumbuhan koloni, pola hemolisis pada agar darah (ó-hemolisis, $\beta$-hemolisis dan $\gamma$-hemolisis) [8]. 


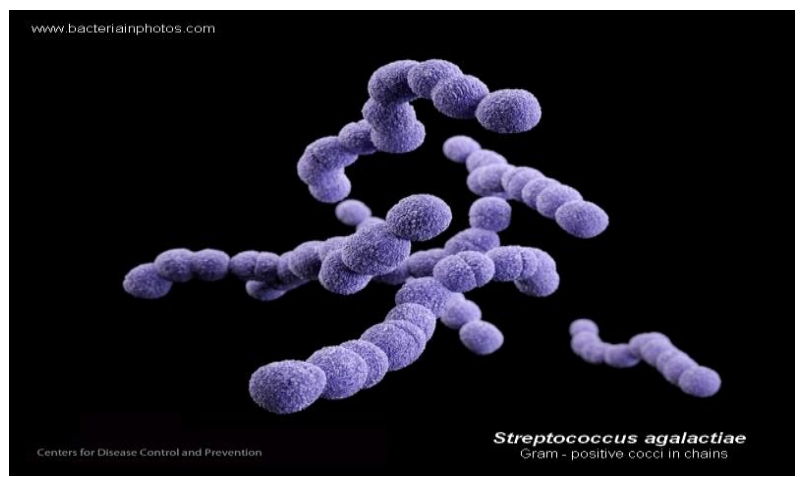

Gambar 1 Streptococcus agalactiae

Gambaran mikroskopis Streptococcus agalactie yang berbentuk coccus dengan membentuk susunan rantai berpasangan

Streptococcus yang menyebabkan penyakit pada manusia terutama berasal dari grup B dan D. Tetapi akhir-akhir ini ditemukan pula grup-grup lainnya yang dapat menjadi penyebab penyakit pada manusia seperti grup B yang dapat menjadi penyebab sepsis puerperalis dan pada anak-anak dapat menyebabkan meningitis, bakterimia asimptomatik, arthritis septika, osteomielitis, selulitis fasialis, etmoiditis, empiema dan konjungtivitis [8].

\section{Faktor Virulensi Streptococcus agalactiae}

Bakteri Streptococcus agalactiae mempunyai beberapa jenis faktor virulensi yang dapat menyebabkan berbagai penyakit pada tubuh manusia (Todar, 2008).Bakteri Streptococcus agalactiae dapat menimbulkan penyakit melalui kemampuannya tersebar luas dalam jaringan dan melalui pembentukan berbagai zat ekstraseluler. Berbagai zat yang berperan sebagai faktor virulensi dapat berupa protein, termasuk enzim dan toksin, antara lain:katalase, Koagulase, Hemolisin, Leukosidin, Toksin Eksofoliatif, Toxic Shock Syndrom Toxin (TSST), dan Enterotoksin.

Berbagai infeksi yang disebabkan oleh Streptococcus agalactiae dimediasi oleh faktor virulen dan respon imun sel inang.Secara umum bakteri menempel ke jaringan sel inang kemudian berkoloni dan menginfeksi.Pertumbuhan dan perkembangan sebagai penyebab infeksi tergantung kemampuan bakteri untuk melawan pertahanan tubuh sel inang (Rostinawati, 2009).Komponen dinding sel Streptococcus agalactiae dapat berupa peptidoglikan, teichoic acid dan lipoteichoic acid.Peptidoglikan dan lipoteichoic acid dapat berfungsi sebagai substansi yang menginduksi sistem imun, sehingga dapat mengaktifkan efektor sistem imun [10]. 


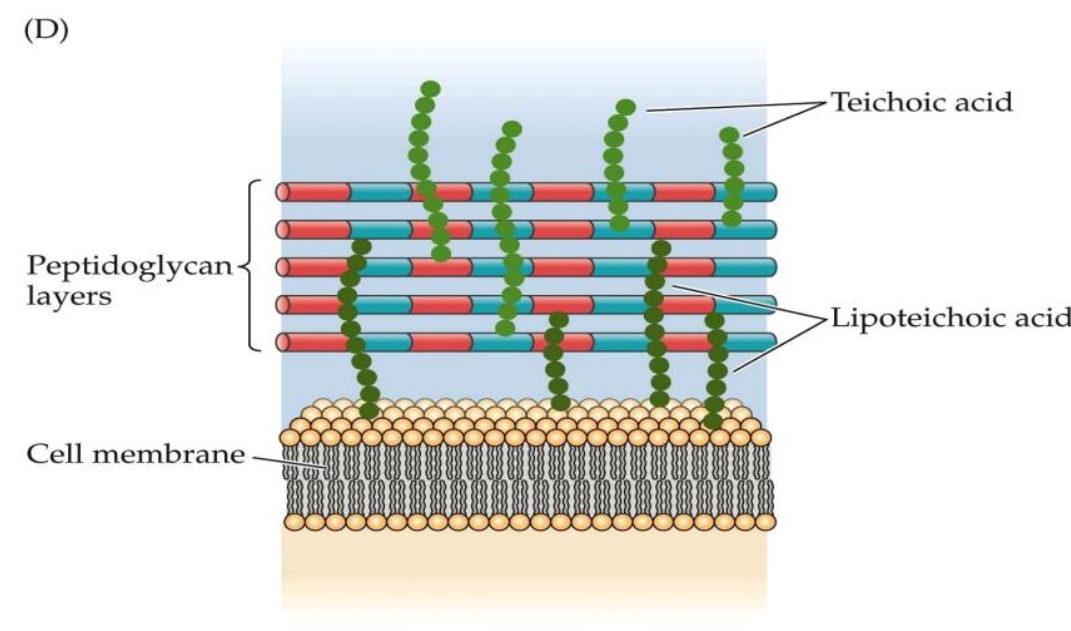

Microbial Life 2e, Figure 4.51 (Part 2)

\section{Gambar 2 Struktur dinding sel bakteri gram positif}

gambaran struktur dinding bakteri gram positif dimana dinding sel memiliki peptidoglycan layer, teichoic acid, lipoteichoic acid dan cell membrane (Todar, 2008)

\section{Tranforming Growth Factor $\beta$ (TGF- $\beta$ )}

TGF- $\beta$ sebenarnya merupakan suatu family dari substansi yang molekul - molekunyal dikodekan oleh gen - gen yang berbeda, yang direpresentasikan pada TGF- $\beta 1$, TGF- $\beta 2$, dan TGF- $\beta 3$. Sel-sel sistem kekebalan tubuh mensintesis terutama TGF- $\beta 1$.Tranforming Growth Factor $\beta 1$ (TGF- $\beta 1$ ) dapat berperan sebagai sitokin proinflamasi maupun sitokin antiinflamasi tergantung pada konsentrasinya. TGF- $\beta$ merupakan immunosupressant yang kuat dengan menekan proliferasi dan maturasi sel $\mathrm{T}$, B dan $\mathrm{K}$ serta menekan aktivitas makrofag.Melalui fungsinya sebagai antagonis sitokin proinflamatori TGF- $\beta$ dapat mengakhiri respon imun dan respon inflamasi. TGF- $\beta$ juga menekan aktivasi sel-sel lain, seperti neutrofil dan sel endotel. Dengan potensi penghambatan ini, maka TGF- $\beta$ berfungsi untuk mengontrol respon imun / kekebalan tubuh dan inflamasi/ peradangan. Kemampuan TGF- $\beta$ untuk menekan respon imun dan inflamasi, sebagian dibentuk dengan cara menginduksi aktifasi sel T regulator [20].

\section{Tanaman Turi Merah (Sesbania grandiflora L.Pers)}

Tanaman turi atau Sesbania grandiflora merupakan tanaman yang berbentuk pohon dan digolongkan ke dalam subfamili Mimosaceae.Tanaman legum ini sudah banyak dikenal di seluruh Indonesia, terutama di wilayah Indonesia bagian tengah dan timur.Daun dari tanaman ini berbentuk lonjong (oval), bersifat majemuk menyirip ganda, dan letaknya tersebar. Panjang daun sekitar 20-30 cm dengan daun penumpu dimana panjangnya sekitar $0.5-1 \mathrm{~cm}$. Anak daun bertangkai pendek dengan jumlah yaitu kurang lebih 20-50 pasang anak daun dalam satu tangkai. Helaian anak daun berbentuk jorong memanjang, tepi rata, panjang $3-4 \mathrm{~cm}$, lebar 0,8-1,5 cm [11]. 


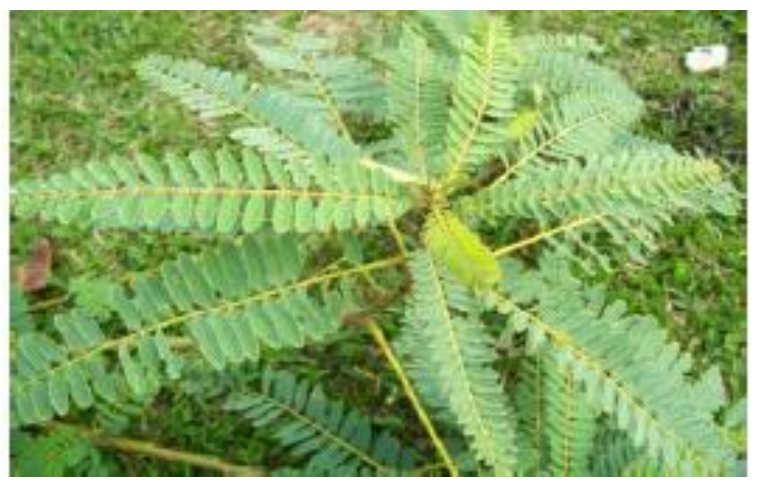

Gambar 2.6 Daun Tanaman Turi Merah (Nasution $d k k$., 2010)

Daun dari tanaman turi ini mengandung Saponin, tanin, flavonoid, peroksidase, vitamin A, dan vitamin B. Selain itu, terdiri dari 77.2\% air, 9.7\% karbohidrat, 8.4\% protein, 2-5\% serat, 3$5.5 \%$ nitrogen, $1 \%$ lemak, kalsium, zat besi, fosfor, natrium, kalium, dan vitamin $\mathrm{C}$

\section{Bahan Aktif pada Daun Turi Merah yang Diduga Memiliki Efek Antibakteri}

Daun turi merah memiliki beberapa kandugan kimia seperti saponin, tanin, flavonoid, peroksidase, vitamin A, dan vitamin B. Terdapat tiga bahan aktif yang diduga memiliki efek sebagai antibakteri yaitu flavonoid, saponin, dan tanin.

- Flavonoid

Bidang farmasi menunjukkan bahwa flavonoid bisa menjadi antioksidan yang baik dan beberapa jenis zat aktifnya juga menunjukkan flavonoid sebagai antimikroba (Bylka et al., 2004).Flavonoid merupakan golongan terbesar dari senyawa fenol.Senyawa fenol mempunyai sifat efektif menghambat pertumbuhan virus, bakteri dan jamur, karena menyebabkan terjadinya kerusakan permeabilitas dinding sel bakteri.Selain itu, flavonoid juga mampu menghambat motilitas bakteri. Terdapat tiga mekanisme kerja flavonoid sebagai antibakteri. Tiga mekanisme tersebut yaitu mencegah sintesis asam nukleat, mencegah berfungsinya membran sitoplasma, dan mencegah terjadinya metabolisme energi.

\section{- Saponin}

Saponin merupakan glukosida yang larut dalam air dan etanol, tetapi tidak larut dalam eter.Saponin paling tepat diekstraksi dari tanaman dengan pelarut etanol $70-96 \%$ atau methanol. Mekanisme kerja saponin sebagai antibakteri adalah dengan menurunkan tegangan permukaan sehingga mengakibatkan naiknya permeabilitas atau kebocoran sel dan mengakibatkan komponen intraseluler keluar (sel bakteri lisis). Proses tersebut akan mengakibatkan kerusakan membran sel dan menyebabkan keluarnya berbagai komponen penting dari dalam sel bakteri yaitu protein, asam nukleat, dan nukleotida [4].

- Tanin

Tanin banyak ditemukan pada beberapa jenis makanan seperti teh, biji kokoa, anggur, dan strawberry. Bahan astringen dari tannin mendorong dan menyatu dengan enzim-enzim dari mikroba, sehingga fungsinya terhambat karena enzimnya tercampur dengan enzim tanin. Mikroorganisme yang tumbuh dalam kondisi aerob membutuhkan zat besi untuk menjalankan fungsinya dan dalam pembentukannya.Tanin melakukan pengikatan zat besi yang mengakibatkan pertumbuhan mikroorganisme terhambat. Koagulasi plasma sebagai pembentuk membran sel tidak muncul, karena penghambatan pertumbuhan pada formasi dari struktur 
membran Staphylococcus aureus.Asam tannin bisa digunakan sebagai agen pembantu yang sangat berguna bagi pengobatan Staphylococcus aureus [11].

\section{PEMBAHASAN}

rerata kadar TGF- $\beta 1$ plasma pada kelompok kontrol positif $(126 \pm 15.43 \mathrm{pg} / \mathrm{mL})$ dengan kelompok perlakuan pemberian ekstrak daun turi merah dosis $125 \mathrm{mg} / \mathrm{kg} \mathrm{BB} / \mathrm{hr}\left(147.83 \pm 12.95^{\mathrm{b}}\right.$ $\mathrm{pg} / \mathrm{mL})$, dengan dosis $250 \mathrm{mg} / \mathrm{kg} \mathrm{BB} / \mathrm{hr}\left(192.83 \pm 10.21^{\mathrm{c}} \mathrm{pg} / \mathrm{mL}\right)$, dan dengan dosis $500 \mathrm{mg} / \mathrm{kg}$ $\mathrm{BB} / \mathrm{hr}\left(173.67 \pm 16.27^{\mathrm{d}} \mathrm{pg} / \mathrm{mL}\right)$ ada perbedaan yang bermakna $(p=0.000)$. Berdasarkan nilai reratanya kadarTGF- $\beta 1$ plasma pada kelompok kontrol jauh lebih kecil nilainya dibandingkan dengan rerata kadar TGF- $\beta 1$ plasma pada kelompok perlakuan. Hal ini berarti bahwa mencit model infeksi nifas memiliki nilai rerata kadar TGF- $\beta 1$ plasma lebih rendah dibandingkan dengan mencit model infeksi nifas yang mendapat ekstrak daun turi merah.

Pada kelompok P1 (dosis ektrak turi merah $125 \mathrm{mg}$ ) kadarTGF- $\beta 1$ mulai meningkat hal ini menunjukkan fungsi dari ekstrak daun turi merah sebagai antimikroba belum maksimal, dan yang muncul adalah fungsi sebagai imunomodulator. Hal ini terjadi karena makrofag teraktifasi sehingga TGF- $\beta 1$ mulai meningkat.TGF- $\beta$ diperlukan untuk aktifasi imun adaptif, yang diperlukan untuk eliminasi antigen.

Pada Kelompok P2 (dosis ektrak turi merah 250 mg) kadarTGF- $\beta 1$ semakin meningkat, hal ini menunjukkan peran sebagi imunomodulator yang semakin kuat untuk aktifasi makrofag. Dengan menurunnya jumlah leukosit darah (rata-rata 7,85 $\pm 2,16$ ) diasumsikan peran ekstrak daun turi merah sebagai antimikroba mulai muncul. Disisi lain diperlukan TGF- $\beta$ untuk aktifasi dari Treg. Mekanisme ini diperlukan agar respon imun dapat dikendalikan. Pada Treg akan disekresikan IL-10, hal ini tampak dari kadar IL-10 yang meningkat pada kelompok P2 (ektrak daun turi merah $250 \mathrm{mg} / \mathrm{kg} \mathrm{BB}$ ).

Pada Kelompok P3 (dosis ektrak turi merah $500 \mathrm{mg}$ ) terjadi penurunan dari TGF$\beta 1$.Hal ini menunjukkan fungsi ekstrak daun turi merah sebagai antimikroba lebih kuat dibandingkan dosis ekstrak turi $250 \mathrm{mg}$. Dengan adanya fungsi antimikroba ini maka kolonisasi bakteri ditekan yang menyebabkan antigen penginduksi aktifasi makrofag berkurang.Dengan berkurangnya makrofag teraktifasi berdampak pada sekresi TGF- $\beta$ menurun.

TGF- $\beta$ sebenarnya merupakan suatu family dari substansi yang molekul - molekunyal dikodekan oleh gen - gen yang berbeda, yang direpresentasikan pada TGF- $\beta 1$, TGF- $\beta 2$, dan TGF- $\beta 3$. Sel-sel sistem kekebalan tubuh mensintesis terutama TGF- $\beta 1$ Tranforming Growth Factor $\beta 1$ merupakan suatu sitokin polipeptida multifungsi yang disekresikan oleh berbagai macam sel dalam tubuh termasuk makrofag, sel natural killer (sel NK), lymphokine activated killer cells, sel B, sel CD4, dan sel CD8 [11]. Tranforming Growth Factor $\beta 1$ (TGF- $\beta 1$ ) dapat berperan sebagai sitokin proinflamasi maupun sitokin antiinflamasi tergantung pada konsentrasinya [5]. Melalui fungsinya sebagai antagonis sitokin proinflamatori TGF- $\beta$ dapat mengakhiri respon imun dan respon inflamasi. Disisi lain TGF- $\beta$ bersama dengan IL-6 dan IL-1 meningkatkan perkembangan sel Th17 yang mensekresikan IL-17 dan IL-22. Perkembangan selsel TH17 tergantung pada faktor transkripsi ROR $\gamma$ t dan STAT3.IL-6 mengaktifkan faktor transkipsi STAT3 dan TGF- $\beta$ mengaktifkan faktor transkripsi ROR $\gamma$ t.faktor transkripsi ROR $\gamma \mathrm{t}$ dan STAT3 mengaktivasi respon Th-17. IL-17 menginduksi polymericIg receptor (pIgR) epitel, sehingga meningkatkan sekresi IgA ke dalam lumen [15]. 


\section{KESIMPULAN}

Pemberian ekstrak daun turi merah (Sesbania grandiflora L. Pers) dapat meningkatkan kadar TGF- $\beta$ pada mencit (Mus musculus) model infeksi nifas yang diinokulasi Streptococcus agalactiae, dosis optimum yang mampu meningkatkan kadar TGF- adalah dosis $250 \mathrm{mg} / \mathrm{kg}$ $\mathrm{BB} / \mathrm{hr}$.

\section{DAFTAR PUSTAKA}

[1] Ahmed, Salma; Kawaguchiya, Mitsuyo. Drug Resistance and Molecular EpidemiologyOf Aerobic Bacteria Isolated From Puerperal Infection In Bangladesh, 2015; 21 number 3.

[2] Surveilans, 2014. Epidemiologi Kematian Ibu dan Target MDGs http://www.Indonesianpublichealth.com/2014/05/surveilans-kematian-ibu-html/fdx.diakses 22 Maret 2016

[3] Direktorat Kesehatan Ibu, 2010-2013 dalam Kementrian Keshatan RI, 2014. Info Datin; Pusat Data dan Informasi Kementrian Kesehatan RI Mother's Day Situasi Kesehatan IBU www.depkes.go.id diakses 22 Maret 2016

[4] Curran, D. 2010. Bacterial Vaginosis.http://emedicine.medscape.com/article/254342overview. download on March, 05, 2016

[5] Post, K W. and Songer, GJ. 2005. MICROBIOLOGY Bacterial and Fungal Agent of Animal Disease. Elsevier Saunders: Philadelphia.

[6] Wang, R., Ding, Y., Liu, R., Xiang, L., \& Du, L. 2010. Pomegranate: Constituents, Bioactivities and Pharmacokinetics. Global Science Books. 4(2): 77-87 Weissenbacher RE, et al. 2013. Immunology of Female Genital TractHal : 184. Springer Science \& Business Media

[7] Wong W Andy et al. 2015. Postpartum infection.Medscape.

[8] Abbas, A. K., Lichmant, A. H. 2015. Cytokines. In: Cellular and Molecular Immunology. . Ed. Philadelpia: W. B. Saunders Company.

[9] E. Rosati, K. Fettucciari, L. Scaringi, P. Cornacchione, R. Sabatani, L. Mezzasoma, R. Rossi \& P. Marconi, 1998. Cytokine Response to Group B Streptococcus Infection in Mice. Scand J. Immunol. 47, 314-323

[10] Damian Clarke, 2012. Role Of CD4+ T Cells In The Regulation Of The Immune Response Against Encapsulated Group B Streptococcus. Département de pathologie et microbiologie Faculté de médecine vétérinaire

[11] Cook DJ, Meade MO, Hand LE, et al, 2002. Toward understanding evidence uptake: semirecumbency for pneumonia prevention.

[12] Luti Simone, Anna Caselli , Cosimo Taiti ,Nadia Bazihizina, Cristina Gonnelli , Stefano Mancuso, and Luigia Pazzagli, 2016. PAMP Activity of Cerato-Platanin during Plant Interaction: An -Omic Approach.

[13] Asplin ,J.R. et all. 2005. Nephrolithiasis dalam Harrison's principles of internal

medicine, edisi 16. New York: Mc graw-Hill. pp:1615-26.

[14] Brooks G.F., Carrol K.C., Butel J.S., Morse S.A. 2007. Immunology. In: R. Nairn, editor: Jawetz, Melnick, and Adelberg's Medical microbiology . 24 th ed. USA:The McGraw-Hill Companies, Inc. p.142

[15] Kresno, S.B. 2013. Imunologi : Diagnosis dan Prosedur Laboratorium. Ed Kelima. Badan Penerbit FKUI : Jakarta

[16] Bylka W, Matlawska I, Pilewski NA. Natural Flavonoid as Antimicrobial Agents.JANA, 2004; 7 (2): 24-31. 
[17] Arunabha, M., and Nayak, S. 2011. Phytochemical and Preliminary Toxicity Study of Sesbania grandiflora (Linn) Flowers.International Journal of Biomedical and Advance Research.

[18] Yusniawati, E. 2015. Efek Antibakteri Ekstrak Etanol daun Turi Merah (Sesbania grandiflora L.Pers) terhadap Staphylococcus aureus Isolat 100-SV secara In Vitro. Tugas Akhir. Tidak diterbitkan, Fakultas Kedokteran Universitas Brawijaya, Malang.

[19] Vipin, K., Arun, G.K., and Rajesh, G. 2011. Antimocrobial Activit of Sesbania Grandiflora (L) Pers. International Research Journal of Pharmacy 2(7): p.85-87

[20] Nuria, M. C., Faizatun A., \& Sumantri. 2009. Uji Aktivitas Antibakteri Ekstrak Etanol Daun Jarak Pagar (Jatropha Curcas L) Terhadap Bakteri Staphylococcus aureus ATCC 25923,Escherichia coli ATCC 25922, Dan Salmonella typhi ATCC 1408. Jurnal Ilmu - ilmu Pertanian, 5 (2): 26-37.

[21] Naim, R. 2004. Atlas Tanaman Obat Indonesia Jilid II. Jakarta:Trubus

[22] Denise A. Kaminski, John J. Letterio, and Peter D. Burrows 2003 Differential Regulation of Mouse B Cell Development by Transforming Growth Factor b1 